\title{
NA “MADRUGADA IRREAL DO QUINTO IMPÉRIO”: DA HISTÓRIA PROFÉTICA EM MENSAGEM DE FERNANDO PESSOA
}

\author{
Daniel Vecchio'
}

Recebido: $24 / 10 / 2015$

Aprovado: 22/06/2016

\section{Resumo:}

Desde a cronística, a história de Portugal inscreve-se num horizonte mítico e profético, história convertida em objeto de lenda e acontecimento de ordem simbólica. Para essa inscrição, veremos que a representação épica da expansão marítima foi fundamental para a manutenção da grandiloquência do passado europeu, sobretudo em Portugal, justamente em momentos de regime e opressão. Por outro lado, veremos que Fernando Pessoa transforma essa herança épica em instrumento de crítica, abrindo-se para o sentido da esperança no que remete ao futuro. Torna-se, assim, necessário frisar que o épico, sob esse enfoque combativo, jamais perdeu seu potencial expressivo, ainda que algumas das suas manifestações tenham recebido um tratamento antitético. Nesse estudo, observaremos como Pessoa aponta, em Mensagem, a existência de uma outra Índia por descobrir, localizada nos recantos do imaginário e da vontade onírica de busca dos próprios portugueses.

Palavras-chave: Épica, História, Profetismo, Portugal, Fernando Pessoa.

\section{THE "DAWN OF THE FIFTH UNREAL EMPIRE ": THE PROFETIC HISTORY IN MENSAGEM OF FERNANDO PESSOA}

\begin{abstract}
:
Since of the chronic tradition, the history of Portugal is based in a mythical and prophetic horizon converted history into legend object and an event of symbolic nature, For the epic representation in Portugal, the maritime expansion is fundamental to maintain the grandiloquence of the moments and oppression. On the other hand, we are going to see that Fernando Pessoa turns this epic heritage in a critical tool, opening himselves for the sense of hope as regards the future. It is therefore necessary to evidence that the epic, in this combative approach, never lost its expressive potential, although its manifestations have often received more antithetical treatment. In this study, we will observe how the portuguese poet points out the existence of another undiscovered India, located in imaginary places and dream of themselves.
\end{abstract}

Keywords: Epic, History, Profetism, Portugal, Fernando Pessoa.

\footnotetext{
${ }^{1}$ Graduado em História e Mestre em Estudos Literários pela Universidade Federal de Viçosa (UFV). Doutorando em História Cultural pela Universidade Estadual de Campinas (UNICAMP). Seu interesse abrange os estudos sobre a Literatura Portuguesa de Viagens, a História e a Historiografia dos Descobrimentos, fazendo parte de grupos de pesquisa como o NEP (Núcleo de Estudos Portugueses da UFV) e o Mare Liberum (Centro de Estudos e Referências sobre a Cartografia Histórica da UNICAMP).
} 


\section{Introdução: intersecções entre épica, história e profetismo em Portugal}

As epopeias são importantes fontes de informações sobre a época de diversas civilizações. Tanto que o primeiro período da História Grega (1200 - 800 a.C.) é chamado pelos historiadores de período homérico porque Homero nos forneceu muitas informações sobre os acontecimentos e as formas de expressão dessa época por meio da Ilíada e a Odisséia. Sua base constituinte, o epos, é "uma demanda simultânea de informações históricas e maravilhosas que estão impregnadas, sob a forma de narrativas fragmentadas e múltiplas, em diversas culturas, [...].” (SILVA; RAMALHO, 2007, p.13).

Para Fidelino Figueiredo (1889-1967), em A épica portuguesa no século XVI (1950), a épica é mais que um verso, é a busca pela peculiaridade, a busca pela "essência nacional, a significação íntima da obra, o que contém de espírito e de intuito nacional" (FIGUEIREDO, 1950, p. 20). Trata-se de uma forma de abordagem mais englobante e cultural que permite uma visão privilegiada da cultura e postula um diálogo comparativo e interdisciplinar de largo alcance histórico e poético.

Nesse sentido, a épica representa a voz e o lugar de um fenômeno muito mais amplo do que a produção poética, pois se insere num processo de construção moral e espiritual ao representar um coletivo que se assume como entidade. A dignificação e imortalização da memória de um povo, através da leitura épica das suas realizações passadas, impõe-se, portanto, como um relevante trabalho cultural e civilizacional desde a antiguidade, reorganizando "conjuntos de crença que assumem o aspecto de alegorias, cujo sentido é determinado pela conjuntura histórica; é uma maneira de exprimir reivindicações que pertencem a um tempo preciso e a aspirações em relação directa com a actualidade histórica.” (FRANCO, 2010, p. 151).

Vale ressaltar que, apesar de a épica se circunscrever no tempo histórico, ela não tem as aporias do discurso histórico em relação ao tratamento dado às fontes e aos vestígios do passado. Heródoto e Tucídides mostraram isso através das diversas fontes materiais, orais e geográficas que utilizaram em suas histórias. No entanto, a presença da épica na história parece ser algo mais do que uma relação complementar. Reparemos que o épico vai sendo reconstituído ao longo da modernidade a partir da pena dos renascentistas e humanistas europeus, que eram contratados para escrever as memórias de uma família, de uma aventura ou mesmo de um reino. No geral, é 


\begin{abstract}
uma tipologia dos mitos das origens e dos futuros das nações que, nessa época foram delineados com grande envergadura nos círculos culturais da maioria dos países europeus, de que se conhece exemplos comparativamente interessantes, particularmente na Espanha, na França, na Alemanha, nos Países Baixos, na Hungria e na Rússia, entre outros. Os estados e os reinos recentes ganham, no dealbar da modernidade, a consciência e a convicção de que têm uma origem muito antiga, inscrita nos primórdios da humanidade. Assim sendo, configuram uma idade de ouro que distingue em excelência a primeira idade das nações. (FRANCO, 2010, p. 151)
\end{abstract}

Esse processo de intersecção entre épica e história é marcado pelo paradigmático mito de origem, visto que nas produções desse período há o estabelecimento de uma dicotomia entre o passado fulgurante e a história atual. Essa dicotomia é demarcada pelo otimismo que caracteriza a visão das origens e o pessimismo do presente:

O já enunciado ideal profético-escatológico de Bandarra - primeiro grito da decadência da gloriosa história portuguesa - tornou-se um valor comunitário e um factor de antíteses. As suas profecias, que previram a ruína do Império Português, começado a construir por D. Afonso Henriques, vão estar na base do impulso restauracionista, eivado ainda do ideal de cruzada que regeu a fundação e expansão de Portugal. (FRANCO, 2010, p. 157)

Sendo assim, a escrita da história assume uma dimensão profética e entra ao serviço da afirmação de uma consciência nacional: "Mas esta nostalgia não se fecha em si própria. Transforma-se em instrumento de combate, de crítica, abrindo para o sentido da esperança no que respeita ao futuro." (FRANCO, 2010, p. 152). Torna-se necessário dizer que o épico, sob esse enfoque combativo, jamais perdeu seu potencial expressivo, ainda que suas manifestações tenham recebido "um tratamento crítico muitas vezes deslocado das questões associadas ao epos ou mesmo à permanência e à transformação da forma épica." (SILVA; RAMALHO, 2007, p. 13).

O Renascimento é um bom caso para demonstrar essa releitura do épico, pois nele podemos observar que há já um início de readaptação da tensão entre os elementos ideológico-epistemológicos da modernidade e a herança da tradição. Nessa tensão, o mito da construção de um império cristão ganhou como que um caráter sagrado e universalizante que tendia estar ao serviço de um imperialismo religioso e ao mesmo tempo comercial e político: “Os missionários, os marinheiros e os soldados portugueses levaram a 


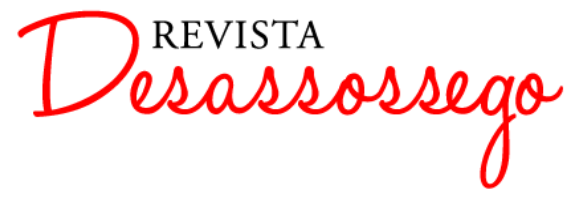

DESASSOSSEGO 15 | JUN/2016 | ISSN 2175-3180

DOI: http://dx.doi.org/10.11606/issn.2175-3180.v8i15p72-88

Palavra de Cristo a todos os povos que encontraram e acreditavam estar delegados especialmente por Deus para tal efeito." (FRANCO, 2010, p. 157).

Isso corrobora o que explica Luis Filipe Barreto ao dizer que o Renascimento "é uma superação da medievalidade e toda a superação, como o ensina Hegel, é um processo de conservação e eliminação.” (BARRETO, 1983, p. 50). O campo simbólico surgido nessa época de transição nos revela uma burguesia técnica e comercialmente em ascensão, mas que por vezes se mostra confiante na origem divina de sua nacionalidade e seu universo ${ }^{2}$.

Cabe salientar que esse profetismo consolida-se também em Portugal, onde pode ser encontrado nas obras de "João de Barros, em Crónica do Imperador Clarimundo e na Rópica Pnefma, na presença franciscana da corte de D. Manuel I (os franciscanos estavam muito influenciados por uma escatologia de inspiração joaquimita e milenarista), na mística dos Descobrimentos e continua emergente com a obra de Diogo Castilho, Origem dos Turcos, [...].” (FRANCO, 2010, p. 157). A sucessão dos acontecimentos na perspectiva dessas obras é representada epicamente através da depuração dos aspectos não dignificantes de um grupo que se quer mostrar divinamente superior e do realce daqueles que são dignos de glória e de exemplaridade, concretizando assim o mito fundacional do reino:

A mitificação das origens primeiras e dos futuros últimos de um povo, de uma nação ou mesmo de uma instituição resulta de um fito de engrandecimento e de legitimação da realidade fenoménica que se descreve num processo de construção de memória histórica. (FRANCO, 2010, p. 151)

É justamente a partir do século XVI que se desenvolve uma espécie de mercado europeu dos imaginários nacionais ou das mitologias nacionais, utilizando fundamentos e materiais do horizonte religioso cristão. "Estamos no momento por excelência da formação genesíaca do mito das nações europeias.” (FRANCO, 2010, p. 151). Todavia, temos que notar que a historiografia moderna evita as cenas mais fantasistas, "as teofanias exageradas, em que Deus ou os seus delegados (anjos e santos) interviriam prolongadamente em determinados passos da História. [...] a tradição lendária é apenas referida sobriamente ou metaforicamente" (FRANCO, 2000, p. 232).

\footnotetext{
${ }^{2}$ Esse contraste reflete na própria reorganização social por que Portugal passava a partir das últimas décadas do século XIV, quando ocorreu a primeira revolução burguesa da história, entre os anos de 1383 e 1385.
} 
Basta observarmos as diversas cenas de guerra em que são registradas evocações divinas: "A matutina luz, serena e fria, / As estrelas do Pólo já apartava, Quando na cruz o Filho de Maria, / Mostrando-se a Afonso, o animava; / Ele, adorando quem lhe aparecia, / Na Fé todo inflamado, assim gritava: / - 'Aos infiéis, Senhor, aos infiéis, / E não a mim, que creio o que podeis!.”' (CAMÕES, 2002, C. III, Est. 45). Os elementos metafóricos e subjetivos utilizados para a descrição de um momento evocativo das batalhas nos induzem, de imediato, à leitura de uma época de complexa transição, demonstrando que o pensamento e a fé permaneciam presentes, mesmo numa sociedade que conhecia cada vez mais a técnica e os elementos da natureza. Esse contraste ocorre, assim como:

cada época recoge el fruto de la precedente. Así, la exaltación de los ideales caballerescos en la "novela cortés" de la Edad Media, a partir del siglo XII, va a granar no sólo en los tardíos "libros de caballerías"', sino en las hazañas con que los hombres del Renacimiento pretendieron emularlas, en la historia y por hechos reales. Los conquistadores vivieron, hicieron ciertas, las andanzas novelescas. Los historiadores de Indias son cronistas de "no mentidas" aventuras. (VALVERDE, 1959, p. 213)

É fato que os cavaleiros que trocaram seus cavalos por caravelas não deixaram de ouvir histórias da chamada matéria da Bretanha, um vastíssimo conjunto de textos antigos provenientes da mitologia, produzidos em verso e em prosa e centrados na figura do rei Artur e seus cavaleiros da távola redonda. O que estamos tentando evidenciar até aqui é que a épica foi praticamente um meio privilegiado para a proliferação de histórias proféticas e doutrinárias na Europa. Apesar de consistirem em técnicas por vezes diferentes, tratados, crônicas e epopeias se interseccionam num mesmo quadro imaginário, tangenciando um passado remotíssimo de reinos com forte feição mitológica, nos quais a grandeza e a sacralidade das origens é a prefiguração daquilo que um povo ou um reino virá a realizar no desenrolar de sua própria história.

Em Portugal, isso pode ser claramente evidenciado, visto que:

sob a autoridade de Bandarra e com o impulso dos Jesuítas, principalmente do Padre António Vieira (1608-1697), o Sebastianismo heterodoxo reforça-se com a independência restaurada em 1640. Este sebastianismo metamorfoseia-se de tal modo que é capaz de identificar o Encoberto sucessivamente com as figuras de D. João IV, D. Teodósio, D. Afonso VI, D. Pedro II e D. João V. (FRANCO, 2010, p. 158) 
Nesse modelo de história magistra, em que "Deus faz e a história é feita" (PESSOA, 2007, p. 53), como no caso de Portugal, a escrita da história assume uma dimensão profética e entra ao serviço da afirmação de uma consciência nacional restauradora. $O$ elemento profético, que fundamenta muito bem essa intersecção entre história e épica que estamos a tratar, se metamorfoseia nos séculos XVIII e XIX, propondo uma mensagem de esperança, prezando por uma idade mais perfeita para a humanidade, em que a coletividade passe a ser o protagonista.

Muitas ideias políticas, como o comunismo, o socialismo, o liberalismo, podem ser entendidas também como formas laicas desse profetismo poético e histórico, e essa perspectiva se prolongará, de uma forma menos apologética e mais literária e filosófica, como observaremos nas obras do poeta português Fernando Pessoa (1888-1935), que será aqui nosso principal exemplo a ser explorado.

\section{A épica pessoana e o modo imaginário de estar no mundo}

É verdade que o Renascimento, na esteira de Jacob Burckhardt (1818-1897), continuará a ser visto somente como uma fase de intensa oposição à Idade Média, uma ruptura na passagem "duma idade de comentadores a investigadores", como descreve António Sérgio (1883-1969) na Breve Interpretação da História de Portugal (1929).

Mas o que constatamos na parte introdutória desse estudo, por outro lado, é que há um pleno desdobramento da tradição através de um processo de mitificação das origens e dos futuros de um povo, de uma nação ou mesmo de uma instituição, resultante de um fito de engrandecimento na construção de memória histórica:

[...], para as camadas subalternas da população e as parcelas letradas resistentes à 'revolução científica', a maravilha e a teratologia a ela associada seguiam tributárias da versão de Sto. Agostinho e Ambroise Paré; ou seja, a natureza consistia, fundamentalmente, num universo de signos divinos a serem decifrados, [...], dando mostras da resistência de certas categorias mentais. (PRIORI, 1994, p. 83).

Entretanto, foi justamente essa espécie de síntese entre o maravilhoso e a experiência que proporcionou a "abertura dum novo e outro espaço e tempo, mas regresso a um corpo de narrativa mítica [...] como originária fonte da existência e do espírito." (BARRETO, 1983, p. 54), abertura essa que Fernando Pessoa soube muito bem adequar 


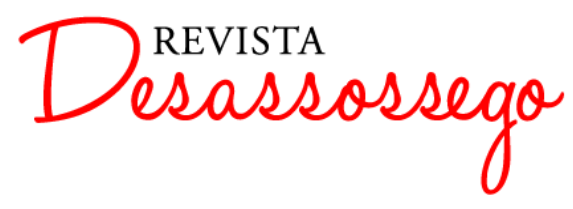

DESASSOSSEGO 15 | JUN/2016 | ISSN 2175-3180

DOI: http://dx.doi.org/10.11606/issn.2175-3180.v8i15p72-88

para sua mística arte poética. Se em Camões o engano entra em tensão com o processo de descoberta, em Pessoa o engano é o motor de um processo de autodescoberta que vamos aqui tentar explicar.

Por começar cabe adiantar que a atualidade e a pertinência do estudo de um texto como Mensagem (1934), de influência profética, está no fato de esse elemento continuar emergente na cultura portuguesa, associado a fenômenos políticos, religiosos, literários e filosóficos, funcionando ora como elemento mobilizador, ora como apelo para a regeneração da sociedade.

Vimos na primeira parte desse breve estudo que se há algo que podemos notar de regular na cultura portuguesa, um elemento serializável, um fato do cotidiano, é a evidência de um elemento épico que, dentre muitos fatores, também modificou a forma do português encarar o mito, não o tomando apenas como um catálogo de ações fantasistas, e sim como destino, o que implica a ideia de descobrir e reavaliar o mito para fazermos uma viagem interior. Por isso, para Pessoa o histórico "ato de navegar é um movimento ao redor de própria razão de ser.” (QUADROS, 1999, p. 129). Não se adiantava Fernando Pessoa ao que décadas depois Mircea Eliade (1972) falará sobre a “importância do mito vivo"? A poética pessoana toma o mito por uma perspectiva que contrasta sensivelmente com a do século XIX, por exemplo. O fato de não aceitar a chegada de Jesus Cristo como o messias que cumpriu a profecia faz de sua poética em Mensagem uma matéria bastante profética.

Ao invés de reproduzir seus predecessores, o mito, na acepção pessoana do termo, é tal como ele era compreendido pelas sociedades arcaicas, em que o mito designa, ao contrário, uma "história verdadeira" e, ademais, "extremamente preciosa por seu caráter sagrado, exemplar e significativo. [...]. De fato, a palavra é hoje empregada tanto no sentido de 'ficção' ou 'ilusão', como no sentido — familiar, sobretudo, aos etnólogos, sociólogos e historiadores — de tradição sagrada, revelação primordial, modelo exemplar" (ELIADE, 1972, p. 6).

Nesse sentido, o essencial a se notar é que

o caráter sagrado dessa relação é configurada num território basilar, e encarnada num povo que transporta de geração em geração esse legado religioso e a vontade nacional, que representam, em suma, o poder sacropolítico totalizante, com capacidade para defender, ordenar e governar a 


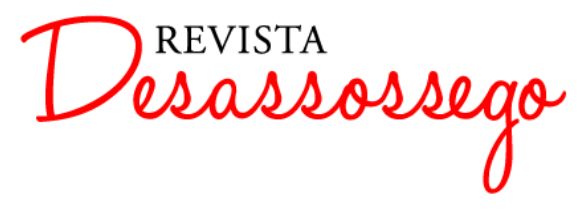

DESASSOSSEGO 15 | JUN/2016 | ISSN 2175-3180

DOI: http://dx.doi.org/10.11606/issn.2175-3180.v8115p72-88

nação fundamentada num discernimento especial, consoante as circunstâncias históricas. (FRANCO, 2000, p. 291)

De Camões até hoje, os paradigmas de imaginação, sensibilidade e estilo decorrem do conhecimento e experiência proveniente da expansão portuguesa pelo mundo e seu projeto milenarista de revelação. O livro Mensagem de Fernando Pessoa herda tais paradigmas ao tematizar Portugal, construindo uma peculiar mescla entre a lírica e a épica por meio de retratos dos seus personagens históricos de Portugal. É provável que, durante a produção de sua poética, Pessoa pouco a pouco tenha amadurecido sua ideia de unir a esse cruzamento uma matéria de inspiração e exaltação do sentimento nacional, como "os mitos do sebastianismo e do Quinto Império, o espírito da gnose e da tradição iniciática, em suma, a totalidade do que ele fala de 'Portugal', que é um livro pequeno de poemas." (BRECHON, 1998, p. 502-503).

A voz épica de Os Lusíadas não pôde ver e viver "o grande Desconcerto do reinado de D. Sebastião, o que foi visto e vivido pelo épico de Mensagem.” (GARCEZ, 1989, p. 92). E esse detalhe fez toda a diferença, visto que Fernando Pessoa escolherá o mito sebastianista como a mais original e singular característica viva da cultura portuguesa, decorrente da sua concepção doutrinária alicerçada na história dos Descobrimentos. Nesse sentido, o mito sebastianista se encontra na origem sociológica e mental dos portugueses, um aspecto coletivo, um diagnóstico geracional não pessimista da representação do além do visível e do aparente dos fatos, com aquilo que constitui a essência mesma de todos os acontecimentos: a manifestação imaginária de um grupo.

Como Os Lusiadas, a Mensagem é também um elogio ao Português, desvendador de mundos, porém, na segunda obra poética há um navegar da alma que lhe é singular, pois, diferente de Camões, Pessoa teve de aprender a ver além do fracasso vivido em AlcácerQuibir, pois "foi na crucificação de Cristo - aos olhos humanos uma enorme e vil derrota que Deus o coroou como vitorioso num outro plano que existe para além do humano, o plano divino.” (GARCEZ, 1989, p. 95).

Seguindo tais coordenadas, a teoria do heroísmo em Pessoa é também uma teoria do sacrifício, que nos versos camonianos são representados superficialmente pelos “enganosos" e "temerosos" caminhos. Os Lusíadas são a epopéia de grandes feitos que já se consumaram, mas também são a epopéia da esperança nos grandes feitos que esperava-se 
vir através do governo de D. Sebastião, por isso temos em Camões uma abordagem situada antes da dita derrota desse rei, o que a torna mais otimista e menos introspectiva.

Essas diferenças adquirem relevo, a começar pelo fato de que, enquanto em Camões o engano e os surtos imaginários fazem o poeta reclamar diretamente a Deus, lamentando as barreiras por ele implantadas para dificultar o cumprimento do caminho marítimo para as Índias e a consequente expansão da fé, em Fernando Pessoa esse engano não provoca uma tensão, não corresponde a um obstáculo. Pois foi no mistério que Pessoa enxergou uma possibilidade de constituição espiritual, de formação da identidade lusitana: "Ah, quanto mais ao povo a alma falta, / Mais a minha alma atlântica se exalta” (PESSOA, 2007, p. 89).

Além disso, nas figuras que compõem a parte chamada as "Quinas", de Mensagem, o desastre e o sacrifício são denominadores comuns. Todos os personagens históricos de Portugal foram marcados pela desgraça e martirizados. "Mas assim, exatamente por meio dessas linhas tortas, que Deus escreveu direito e Portugal se foi fazendo e foi cumprindo um determinado fazer no mundo.” (GARCEZ, 1989, p. 96).

Ainda devemos tomar conhecimento da estrutura espaço-temporal de ambas as obras: se Os Lusíadas recontam cronologicamente a história de Portugal até seu momento de escrita, Mensagem interrompe seu percurso temporal repleto de lacunas, caracterizando as personalidades históricas de acordo com a "espera profética do retorno do Encoberto, o rei D. Sebastião, morto em batalha, e que, por meio da figura de algum outro expoente histórico, reerguerá o Império português.” (GAGLIARDI, 2007, p. 17):

Diferentemente de Camões, aos heróis da épica pessoana, pouco parece importar a aventura temporal. Analisando bem, todos esses heróis são, na verdade, protagonistas de uma aventura muito mais mística do que material, e é aquela que interessa à voz épica pessoana. Todos esses seres afinal não estão mortos e é por isto que, alguns, o poeta os invoca, clamando por sua proteção. Há como que uma visão atemporal dessas personagens, que estão como que pinçadas do tempo, formando uma galeria de eternidade; elas não cumpriram uma missão e desapareceram, não se caracterizam pela ausência, mas por um eterno olhar, por uma eterna presença. [...] Mensagem não percorre cronologicamente a História. Seu critério é outro. Ele ziguezagueou pela História, escolhendo personagens que considera decisivas sob o prisma anagógico com que a lê, deixando outras de lado. Isto porque seu desígnio maior não é o de informar, nem mesmo o de encontrar e comover (como faz Camões), mas o de interpretar a História sob o ponto de vista da intervenção 
divina nela; é isto o que mostra em cada uma das figuras focalizadas. (GARCEZ, 1989, p. 97)

Demasiado grande é a sombra de Camões em Mensagem, fazendo-o interlocutor em cada retrato histórico representado nesse livro de poesias. Contudo, nessa intertextualidade, Fernando Pessoa estatui o termo "engano" como uma criação coletiva, onírica e delirante, "resultado de uma alucinação inicial, correspondente a um profundo mal-estar dos portugueses que não encontram explicação racional para o permanente estado de falência e insucesso que tem conduzido o país desde o século XVII.” (REAL, 2013, p. 6).

Dessa forma, responde Pessoa às muitas indagações que Camões faz a Deus sobre os enganos e os temores que surgiam ao longo da viagem histórica de Vasco da Gama, sendo, em Mensagem, esse estado crítico projetado na ordem da providência e do messianismo, isto é, para a esfera do espiritual:

Louco, sim, louco, porque quis grandeza

Qual a Sorte a não dá.

Não coube em mim minha certeza;

Por isso onde o areal está

Ficou meu ser que houve, não o que há.

Minha loucura, outros que a tomem

Com o que nela ia

Sem a loucura que é o homem

Mais que a besta sadia,

Cadáver adiado que procria?

(PESSOA, 2007, p. 61).

O que é o homem sem a loucura? Ou o que somos sem o mito? Entre esses questionamentos, retoma o poeta de Orpheu o cenário do areal de Alcácer, imagem que possivelmente pode ter figurado a última visão do rei D. Sebastião no momento de sua morte. Esse rei era clamado pela população para reorganizar o império luso, firmando a identidade e a colonização efetiva das terras estrangeiras sob domínio português. Sua morte em território africano acentuou o caráter lendário da cultura de seu povo, que passou a simbolizar a sua volta como o retorno do rei que cumprirá o desígnio divino e imperial registrado desde sua fundação.

De reinado surgido pela conquista cristã da Península Ibérica, Portugal passaria a império a expandir a cristandade por todo o mundo. O mito sebastianista, correspondendo ou não à verdade histórica, é a representação de um sentimento coletivo que funda esse 


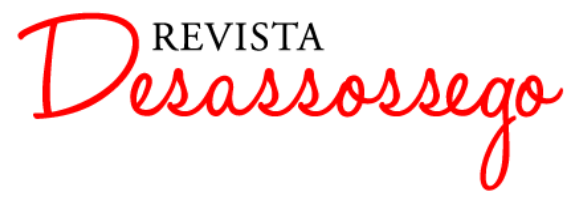

DESASSOSSEGO 15 | JUN/2016 | ISSN 2175-3180

DOI: http://dx.doi.org/10.11606/issn.2175-3180.v8i15p72-88

desejo, ou seja, o sebastianismo, como define Eduardo Lourenço, constitui o "máximo de existência irrealista” de Portugal, mas também "o máximo de coincidência com o nosso ser profundo, já que representa a consciência delirada de uma fraqueza nacional, de uma carência, e essa carência é real" (LOURENÇO, 1989, p. 24-25).

O império da conquista pode até ter falhado, mas sem ele "não poderia o império cultural buscar o apoio, pois não teria idéia de império alguma em que se apoiasse" (GARCEZ, 1989, p. 99). Mensagem singulariza-se, assim, como um épico sem cantos e instrumentos ruidosos, mas de secretas e miríficas irrealidades da alma:

O idealismo estreme, ocultista ou platônico, dalguns dos seus poemas líricos reduz o mundo visível a cópia grosseira do mundo invisível. Aqui sobre a terra $<<$ tudo é nocturno e confuso $>>$, tudo são projecções, sombras, fumo dum lume escondido; no outro mundo é que vivemos como almas. A Mensagem reafirma a cada passo a mesma repugnância pelo carnal, pelo que o sonho ou a loucura não redimem: [...]. (COELHO, 1969, p. 52)

Uma espécie de confusão lírica em Mensagem constitui o fator ontológico da épica profética pessoana. Sua veia lírica pode ser percebida claramente num poema sem titulo na sessão intitulada "Os avisos", que compõe a terceira parte "O Encoberto". Nesse poema, apresenta-se o próprio poeta escrevendo suas poesias "à beira-mágoa. / Um coração não tem que ter. / Tenho meus olhos quentes de água. / Só tu, Senhor, me dás viver." (PESSOA, 2007, p. 109).

O poeta questiona qual é o grande feito português, e não responde com o achamento do caminho marítimo para as Índias, com a descoberta do Ocidente ou a constituição do Império:

O grande feito português, na visão Sebastiana e messiânica que preside Mensagem, está na iminência de vir (“É a Hora!"); aqueles primeiros acontecimentos foram apenas os sinais deste último, que é o verdadeiro e que é o grande Concerto que o mundo espera. Como é sabido e foi provado que Pessoa não aceita a Revelação Cristã tal como no-la apresenta a Igreja, há uma identidade do homem que nela é desvendada, mas que o poeta de Orpheu repele; para ele continua a subsistir uma indagação acerca das origens do homem, da sua identidade portuguesa. Se nos Lusíadas a grande preocupação com identificar e "contar" uma História que mantenha a identidade e demonstre um finalismo que abre para o mundo da Revelação cristã é patente, em Mensagem, Pessoa, que não resolve assim este problema, recoloca a indagação sobre as origens e propõe esta nova meta para a busca: [...]. (GARCEZ, 1989, p. 100-101) 
Em Mensagem, portanto, revela-se uma mescla de gêneros e épocas, não festejando Portugal apenas no sentido de cantar feitos heróicos e conquistas, nutrindo pelo país uma ternura mais triste. Conforme Cleonice Berardinelli, "a criação de símbolo a partir de uma realidade ou a deformação dessa realidade, a fim de torná-la simbólica, implica um subjetivismo bastante acentuado, o que nos faz dizer que Mensagem é um poema épicolírico” (BERARDINELLI, 2004, p. 131).

Nessa base lírica, o mito não é tomado como uma invenção ou uma falha, espécie de cegueira ou alienação, como pensava sociologicamente António Sérgio, mas sim a cura para o sintoma de decadência que há tempos persegue a nação: "Pois venha o que vier, nunca será, / Maior do que a minha alma” (PESSOA, 2007, p. 58). Pelo contrário, para Pessoa "as potências do invisível fecundam a realidade, tornam a vida digna de ser vivida, ou melhor, transformam a existência, mero vegetar, em vida” (COELHO, 1969, p. 53). Essas potências é que mantêm a "Sperança consumada, / S. Portugal em ser, / Ergue a luz da tua espada / Para a estrada se ver!” (PESSOA, 2007, p. 65).

É nessa perspectiva que se inicia o poema Ulisses, onde, sem existir, Ulisses funda Portugal, um ato fundacional completamente atrelado ao imaginário: "Este que aqui aportou / Fiz por não ser existindo. / Sem existir nos bastou. / Por ao ter vindo foi vindo / E nos criou. // Assim a lenda se escorre / A entrar na realidade, / E a fecundá-la decorre.” (PESSOA, 2007, p. 47). É preciso compreender que o mito pessoano fecunda a história, fertiliza o mensageiro e, por fim, proporciona vida.

Ainda segundo Cleonice Berardinelli, o que constitui o cerne do poeta Fernando Pessoa é justamente essa "febre de Além" (BERARDINELLI, 2004). Tal imperiosa necessidade de sonhar, de imaginar, já se assinalou no poema dedicado a D. Fernando através da presença do mistério e do oculto: "Pôs-me as mãos sobre os ombros e douroume / A fronte com o olhar; / E esta febre de Além, que me consome, / E este querer grandeza são seu nome / Dentro em mim a vibrar.” (PESSOA, 2007, p. 58).

Uma espécie de inquietação imaginária seria uma das componentes dessa "febre de Além", febre que é atribuída ao infante D. Fernando, por reconhecer legislativamente o sonho de uma Índia rica de todo trato. Em Mensagem, é D. Fernando quem praticamente inicia esse surto imaginário, visto a importância que deu esse rei à atividade marítima ao criar e fortalecer as leis protetoras do comércio marítimo. Isso "revela-nos o valor da 
burguesia marítima, e mostra em germe o que veio depois: a revolução de 1383 e a mística empresa das navegações.” (SÉRGIO, 1978, p. 26).

Se em Os Lusíadas a saga de um povo é narrada por uma persona poética que se confunde com a imagem do próprio Camões, Mensagem é um espaço dispersivo por excelência, uma aquarela de vozes: “é, às vezes, o monólogo da figura heróica que intitula suas partes, noutras é a voz de um eu-lírico distanciado e impessoal, que se manifesta tanto na primeira pessoa do singular quanto na primeira do plural; e em outros poemas é uma voz que se dirige para a figura-título do texto”. (GAGLIARDI, 2007, p. 17-18)

É através de um trabalho de empatia e misticismo que Fernando Pessoa arriscará, como um Colombo, navegar até a alma dos heróis e mártires portugueses, como no caso de D. Fernando e dos outros cavaleiros responsáveis pela edificação do destino português. Cavaleiros como D. Dinis e D. Sebastião se tornaram mártires em Portugal por sacrificarem suas vidas na tentativa de efetivar o mito imperial de sua nação, obtendo o missionário sinal da cruz em seu escudo real.

Histórias exaltadas com tanta subjetividade só poderiam ser representadas através da primeira pessoa, atingindo assim os poemas de as "Quinas" um eu-lírico em seu mais profundo martírio e frenético sonhar: "Tudo vale a pena / Se a alma não é pequena. / Quem quer passar além do Bojador / Tem que passar além da dor” (PESSOA, 2007, p. 88). Desbravar o mar desconhecido, conviver com e descobrir seus próprios medos e limites em prol do fortalecimento e enriquecimento de si, além do seu rei e reinado, é o que Fernando Pessoa almeja para os portugueses do futuro, comunicando ao seu leitor a sua meditação poética sobre a história e a cultura da nação lusa:

O que a Mensagem põe em cena numa série de 44 retratos históricos cada um dos quais, um brevíssimo drama - é a "febre" de se perder no que é grande, maior que tudo: o indizível e incomensurável. $\mathrm{E}$ a ação de todos esses heróis - já que são todos conquistadores -, guiada por seu sonho, por sua fé e por sua esperança, é imagem do sonho, da fé e da esperança do poeta, cujo gesto de escrever se situa num espaço para além de toda e qualquer ação possível. (BRECHON, 1998, p. 507)

Se Vieira crê ardentemente na volta do messias lusitano, que surgirá para restaurar a ordem e o império português, que se encontrava então sob domínio de Castela, Fernando Pessoa, por sua vez, parece se ater mais ao ato de acreditar na prática da fé mística de seu país como uma ação eficiente que proporcionará aos portugueses alguma chance de 
reabilitação. Para manter essa crença em suspenso, insiste o poeta em explorar imagens de ambientes sombrios e noturnos, imagens sem contornos definidos em meio à neblina: "num mar que tem tempo ou 'spaço, / Vejo entre a cerração teu vulto baço / Que torna." (PESSOA, 2007, p. 89).

$\mathrm{Na}$ Bíblia, as névoas significavam a presença de Deus em algum lugar³. Em Mensagem, ela produz imagens impressivas, gera dúvida, provoca crendices e suscita vestígios de identidade. "Tudo é incerto e derradeiro. / Tudo é disperso, nada é inteiro. / Ó Portugal, hoje és nevoeiro..." (PESSOA, 2007, p. 118). O nevoeiro aqui consiste na suspensão do mito, que, encoberto de névoa, não é desvendado. Essa imagem favorece e alimenta a esperança dos portugueses pelo retorno do messias e, principalmente, pelo retorno de uma melhor condição de vida. É da invisibilidade e da imprevisibilidade do tempo profético que se retira a energia para manter aquecido os mitos da alma portuguesa: “Que as forças cegas se domem / Pela visão que a alma tem!” (PESSOA, 2007, p. 100).

Reina a dúvida e a incapacidade de enxergar por entre as nuvens, mas ainda persiste a busca pelo encoberto, pela hora e pela era tão esperadas, visto que em Mensagem é do mais espesso nevoeiro, da indeterminação e da irresolução que virá a salvação, ainda que tardia: “Cumpriu-se o Mar, e o Império se desfez. / Senhor, falta cumprir-se Portugal!" (PESSOA, 2007, p. 77). É em meio ao nevoeiro que se espera cumprir o mito que é Portugal, metáfora que pode ser interpretada pela necessidade que o país tem de alcançar um grau mais avançado de vida espiritual, a ponto de esses mitos duradouros obterem uma presença que se faz contínua na vida da população. São profundas experiências de autoconhecimento ou, metaforicamente, de autonavegação à luz de espiritualidades que tornam a vida mais harmônica e menos sofrida. Não que o poeta esteja clamando por uma maior catequização do país, pois versos como encontramos no ortônimo, "Em Deus... Mas o que é Deus? E existe Deus? / E isso que importa?” (PESSOA, 2010, p. 34), revelam as possibilidades quanto à existência de uma linha reflexiva agnóstica em sua poética.

Pessoa preza é pela oração, por um exercício espiritual que visa a uma consciência mais viva de Portugal, tendo o próprio país como destino, realidade e problema ontem e hoje. Para compreendermos melhor esse pensamento proposto pela poética de Mensagem,

\footnotetext{
3 “ $<<$ Virei até ti na espessura da névoa $>>$, diz Iavé a Moisés; e é igualmente numa nuvem que ressoa, sobre a montanha da transfiguração, a voz que diz: <<Este é o meu Filho bem-amado>>." (BRECHON, 1998, p. $509)$.
} 
devemos apreender a sugestão de Filipe Barreto no que concerne ao entendimento dos tempos de ruína como campos férteis para o ressurgimento de mitos e utopias: "O aumento das sombras e não-saídas do real produz o aumento e a força das luzes arejadas do ideal" (BARRETO, 1978, p. 276).

Nessa esteira de ideias, respondendo a uma entrevista feita pelo jornalista Augusto da Costa em 1934, Fernando Pessoa afirmava a sua confiança em que Portugal poderia voltar a ser:

uma grande potência construtiva ou criadora, um Império, não já no sentido evidentemente de um Império guerreiro, territorial ou material, mas no sentido de um Império do Espírito, um Império da Cultura. Para tanto, seria necessário antes de mais nada levantar o moral da nação, abatido pelo complexo de inferioridade em que caímos historicamente. Ora, disse Pessoa, só há uma espécie de propaganda com que se pode levantar o moral de uma nação - a construção ou renovação e a difusão consequente e multímoda de um grande mito nacional. E, mais adiante, significativamente: Temos, felizmente, o mito sebastianista, com raízes profundas no passado e na alma portuguesa. Nosso trabalho é pois mais fácil; não temos que criar um mito, senão que renová-lo. (QUADROS, 1999, p. 247).

A névoa, a bruma, as ilhas são o cenário pessoano por onde se move o mito sebastianista renovado, reconstituído de "pressagos mistérios". Em Mensagem,

o passado português transitou da história para o mito e só nesse será possível a recuperação, só nesse haverá a hora, prometida no último momento do último poema e possibilitada pelo único verso que quebra a negatividade total do texto a ela ligando-se pela rima. (BERARDINELLI, 2004, p. 129).

Observamos que, em Mensagem, o pensamento do poeta está quase inteiramente voltado para o "oculto", mas aplicado à história, à memória coletiva, ao mito nacional. Não podemos exigir dos poetas a fundamentação e o rigor dos sociólogos, mas é fato que a obra poética aqui comentada aponta caminhos valiosos para se pensar a respeito da história e da cultura portuguesas. No entanto, sua matéria-prima,

o mito sebastianista [bem como outros mitos constituintes da cultura lusitana], tem sido pouco estudado e, não raro, desprezado pela elite cultural portuguesa, permanecendo para esta válida a consigna de Agostinho de Macedo, registada há cerca de duzentos anos, de que o sebastianismo nos envergonha como povo civilizado da Europa. No 
entanto, espantosamente, o mito sebastianista, independente do juízo positivo e negativo que sobre ele se faça, constitui um dos pontos de referência culturais mais vinculativos de nossa identidade nacional, merecendo ser estudado sem preconceitos esotéricos ou sociológicos. Aliás, como evidenciamos, só se compreenderá verdadeiramente o mito sebastianista quando se cruzarem num quadro conceptual unitário e coerente os estudos sobre o imaginário simbólico e os estudos científicos de caráter sociológico, não sobrevalorizando um em detrimento do outro. (QUADROS, 1999, p. 8-9).

Nessa conjuntura, vale destacar as palavras de Vitorino Magalhães Godinho (19182011) ao dizer que "a história [...] crescera ao serviço de reivindicações nacionais e na obsessão das prioridades no descobrir e ocupar” (GODINHO, 2008, p. 25). Em seu clássico $A$ Expansão Quatrocentista Portuguesa, obra censurada pela comissão organizadora das Comemorações Henriquinas em 1960, torna-se muito evidente a sua ideia de que só uma sociologia histórica é capaz de nos elucidar o que representou de fato a épica para a coletividade lusitana.

Todavia, se as relações de força da imaginação se perdem nos psicologismos e nos realismos contemporâneos, se a racionalidade se desagrega totalmente com a emergência de uma civilização imediatista industrial e pós-industrial, a épica, na ótica pessoana aqui observada, ajuda a não deixarmos de produzir sentido no mundo, mesmo com base numa visão, numa vivência, "ancorado nas instâncias profundas da consciência - individual ou colectiva - organizando e regulando a totalidade do ser colectivo, num dado espaço e num dado momento da sua existência, isto é, no continuum espaço-tempo" (BUESCU, 1989, p. 39-40).

A singularidade de Mensagem culmina exatamente nessa busca existencial, traços de experiência mística e sabedoria oculta. Para a cultura portuguesa, essa ontologia tornou Pessoa mais do que um escritor ou mesmo um poeta, antes um profeta como o Bandarra ou Vieira, um poeta e viajante como Camões, "olhando em visão espectral a alma encoberta da sua pátria e tudo fazendo para levantá-la, salvá-la, fazê-la reaparecer da espessa névoa que a envolve" (QUADROS, 1999, p. 251).

\section{Bibliografia}

BARRETO, Luís Filipe. Utopia e Heteropia. In: Brotéria, vol. 106, no 3, 1978, pp. 275-279. 1983. . Descobrimentos e Renascimento: formas de ser e pensar nos séculos XV e XVI. 2. ${ }^{a}$ Ed. Lisboa: INCM,

BERARDINELLI, Cleonice. Fernando Pessoa: outra vez te revejo. Rio de Janeiro: Lacerda Editor, 2004. 
BRECHON, Robert. Fernando Pessoa. Estranho estrangeiro. Rio de Janeiro: Record, 1998.

BUESCU, Maria Leonor Carvalhão. Derivas e invariantes da épica portuguesa do século XVI. In: VIEIRA, António Braz de (org.). Fidelino de Figueiredo. Lisboa: Biblioteca Nacional, 1989.

CAMÕES, Luís Vaz de. Os Lusíadas. São Paulo: Nova Cultural, 2002.

COELHO, Jacinto do Prado. Diversidade e unidade em Fernando Pessoa. Lisboa: Editorial Verbo, 1969.

Portugal imaginário e verdadeiro na poesia portuguesa. In: Camões e Pessoa, poetas da utopia.

Lisboa: Publicações Europa-América, 1983, pp. 129-134.

ELIADE, Mircea. Mito e Realidade. Tradução de Pola Civelli. São Paulo: Perspectiva, 1972.

FIGUEIREDO, Fidelino de. A épica portuguesa no século XVI. Lisboa: IN-CM, 1950.

FRANCO, José Eduardo. O Mito de Portugal: a primeira História de Portugal e a sua função política. Lisboa: Roma Editora, 2000.

Profetismo e a ideia de nação: modelação religiosa do destino de um povo. In: Religare. João Pessoa, vol. 7, n. 2, 2010, pp. 150-163.

GAGLIARDI, Caio. A pátria de sonho portuguesa (Prefácio). In: PESSOA, Fernando. Mensagem. São Paulo: HEDRA, 2007.

GARCEZ, Maria Helena Nery. Do Desconcerto e do Concerto do Mundo em Mensagem. In: Trilhas em Fernando Pessoa e Mário de Sá-Carneiro: coletâneas de artigos e ensaios. São Paulo: EdUSP, 1989, pp. 89-107.

GODINHO, Vitorino Magalhães. A Expansão Quatrocentista Portuguesa. 2. edição. Lisboa: Dom Quixote, 2008..

LOURENÇO, Eduardo. O Labirinto da Saudade. Psicanálise Mitica do Destino Português. 2. ${ }^{\text {e }}$ edição. São Paulo: Publicações Dom Quixote, 1989.

Mitologia da saudade: seguido de Portugal como destino: dramaturgia cultural portuguesa. São Paulo: Companhia das Letras, 1999.

PESSOA, Fernando. Mensagem. São Paulo: Hedra, 2007.

Ascensão (poema). In: CRUZ, João Paulo. Pessoa e Deus - uma antologia de espiritualidade pessoana. Lisboa: Companhia da Palvra - Serviços Editoriais, 2010.

PRIORI, Mary del. A história cultural entre monstros e maravilhas. In: SWAIN, Tânia Navarro (org.). História no plural. Brasília: Editora da UnB, 1994, pp. 65-92.

QUADROS, António. O primeiro modernismo português. Lisboa: Europa-América, 1999.

REAL, Miguel. Nova Teoria do Sebastianismo. Lisboa: Publicações Dom Quixote, 2013.

SÉRGIO, António. Breve Interpretação da História de Portugal. Lisboa: Livraria Sá da Costa Editora, 1978.

SILVA, Anazildo Vasconselos da; RAMALHO, Christina. História da epopéia brasileira: teoria, crítica e percurso. Rio de Janeiro: Garamond, 2007.

VALVERDE, José Filgueira. Influencia de la literatura caballeresca em los conquistadores y em los cronistas de índias. In: Enseñanza Media, no 37, 1959, pp. 213-226. 